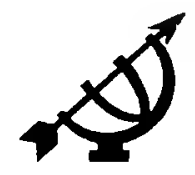

\title{
Van der Vyver's analysis of rights: a case study drawn from thirteenth-century canon law
}

\author{
Charles J. Reid, Jr. \\ School of Law \\ Emory University \\ Atlanta \\ Georgia \\ USA \\ E-mail: creid@law.emory.edu
}

\begin{abstract}
Van der Vyver's analysis of rights: a case study drawn from thiteenth-century canon law

In an important article published in 1988, Johan Van der Vyver challenged the prevailing reliance on Wesley Hohfeld's taxonomy of rights. Hohfeld's division of rights into claims, powers, privileges and immunities, Van der Vyver stresses, is excessively concerned with "inter-individual legal relations" at the expense of the right-holder's relationship to the object of the right. Van der Vyver proposes instead that an assertion of right involves three distinct juridic aspects:

- legal capacity, which is "the competence to occupy the offices of legal subject;

- legal claim, which "comprises claims of a legal subject as against other persons to a legal object";

- legal entitlement, which specifies the boundaries of the right-holder's ability to use, enjoy, consume, destroy or alienate the right in question.

This article applies Van der Vyver's taxonomy to the operations of thirteenthcentury canon law, and demonstrates that Van der Vyver's analysis provides greater depth than Hohfeld's, in that it considers both the relationship of the person claiming a particular right and the object of that right.
\end{abstract}

\section{Introduction}

In the world of American law schools, Wesley Hohfeld seems to have become the generally accepted foundation for analyses of rights (Hohfeld, 1923). His 
division of rights into claims, powers, privileges, and immunities enjoys near universal appeal in the United States (Hull, 1995:245-281; Singer, 1982:986994, 1056-1059). But Hohfeld's analysis of rights is not the only possible approach one might take. Johann Van der Vyver has developed an alternative analysis that has much to recommend (Van der Vyver, 1988). Van der Vyver in particular has challenged Hohfeld's analysis of rights as excessively concerned with "inter-individual legal relations" at the expense of analysing the relationship of the right-holder to the object of the right (Van der Vyver, 1988:207). Additionally, Van der Vyver suggests that Hohfeld was, to a certain extent, disappointed by the language he chose to write in - English. English (like Latin, and unlike some of the other Germanic languages) has failed to develop a legal vocabulary that distinguishes between the claim that one rightfully asserts and the underlying contents of the right one possesses. Van der Vyver has undertaken to remedy these defects, at least insofar as private rights are concerned (Van der Vyver, 1988:209-219).

Building on the jurisprudential writings of Jean Dabin (1952); Milhollin (1970) and Herman Dooyeweerd, 1 Van der Vyver sees the term "right" in English (and by extension, subjective ius in Latin) as having three potential meanings. It can signify, first, the legal competence or power one has to exercise a particular "right"; secondly, it may signify the claim one has to a particular "right"; and finally, it may signify the bundle of "entitlements" that comprise the particular right. This analysis, in essence, asks three questions:

- Is one legally capable of exercising a particular right?

- Can one protect this right from third-party interference?

- What, precisely, is the range of actions one can take with respect to the object of the right?

Inattentiveness to these three questions, Van der Vyver charges, has led to a great deal of confusion in modern analytical writing about rights. Van der Vyver uses an example drawn from an account of modern property law to illustrate the confusion that can result from the failure to draw the proper distinctions. An

1 Writing with the intention of developing a specifically Calvinist jurisprudence, which would be respectful of the proper position of the person with regard to the state and society, Herman Dooyeweerd distinguished three essential aspects to legal rights: (1) the subject of a right, who is a person possessing the legal competence to exercise a right; (2) the legal "object" or entitlement, which amounts to the right's content, and which the person is free to use and to enjoy within the limits set by the terms of the entitlement; and (3) the legal claim or "interest" which the person may assert and which protects the preson from third-party interference. Dooyeweerd's analysis of rights differs significantly from Hohfeld's in its emphasis on the structural relationships implicated by rights-language (Witte, 1993; Marshall, 1985) I am grateful to John Witte, Jr., for introducing me to the work of Herman Dooyeweerd. 
author has defined the conception of ownership as "one right consisting of various other rights (as well, of course, duties)" (Lewis, 1985:243). This definition, however, misses the basic structural relationships implicated by rights language. As Van der Vyver (1988:218) puts it:

There is a difference between, on the one hand, the structural relationship of a legal subject and a legal object as against third persons, which structural relationship is called ownership, and, on the other hand, the entitlement of the owner and (in the event of certain iura in re aliena) of other persons to use and enjoy the object concerned

Like Hohfeld, Van der Vyver would like to confine the meaning of the word right to that of a claim. One ought to use words other than "right" (or ius) to signify the capacity to exercise a right or to designate the entitlements that comprise it.

This article intends to employ Van der Vyver's analysis of rights as a means of studying the juridic structure of thirteenth-century canon law. ${ }^{2}$ The canon law of the twelfth and thirteenth centuries, it is increasingly clear, is an important early matrix for Western conceptions of subjective rights (Tierney, 1989; 1997; Reid, 1991 ; 1996). By subjecting canon law to this sort of analysis, the following discussion is intended to reveal three facts about the canonistic rightsvocabulary of the thirteenth century:

- Legal competence is often put in terms of having a ius.

- One can, furthermore, identify in the canon law of the thirteenth century the same structural relationships that prevail in modern law between right-bearer and third parties, and right-bearer and the object of the right.

- The canonistic rights-vocabulary (much like the modern English rightsvocabulary) does not make consistently clear the structural distinction between the claim portion of a right and the underlying entitlement.

\section{Legal capacity}

\subsection{Van der Vyver on legal capacity}

By legal capacity, Van der Vyver (1988:209-210) means:

2 In carlier studies, I have explored the applicability of Hohfeldian categories of rights to the canon law of the thirteenth century (Reid, 1991:64-72) and the relationship of ius to potestas, facultas, libertas, and immunitas (Reid, 1996:312-331). 
a) The competence to occupy the offices of legal subject, for instance the juridic ability to be a spouse, testator, owner of property, director of companies, executor or trustee of an estate, etcetera; and

(b) the competence to exercise the functions and to be the bearer of the rights and obligations emanating from such offices.

Van der Vyver's analysis implicates two distinct questions:

- Can a particular person be said to possess the juridic capacity "to occupy the offices of a legal subject", that is, is he or she legally empowered to fill a particular role in a legal system?

- Can a particular person be said to possess the juridic capacity to exercise "the rights and obligations emanating from such offices"?

\subsection{The canonists on legal capacity}

The canonists used the term ius to signify both aspects of legal capacity. This much is clear from their discussions of the ius eligendi, the right to vote. Voting was a regular feature of diocesan governance in the twelfth and thirteenth centuries and an entire title of Gregory IX's Liber Extra (1234) is given over to this subject. ${ }^{3}$ Bernard of Parma, Hostiensis and other leading commentators on the thirteenth-century canon law distinguished between an active right to vote (ius eligendi active) and a passive right of being elected (ius eligendi passive). ${ }^{4}$ The ius eligendi passive corresponds neatly to "the competence to occupy the offices of legal subject". One who had the ius eligendi passive had the capacity to be elected to office.

The operation of the ius episcopale, the term the decretalists employed to signify the complex of powers, privileges and prerogatives the diocesan bishop could exercise in virtue of his office, provides an illustration of the second aspect of legal competence, namely the competence to exercise "the rights and obligations emanating from such offices". This is the significance of the phrase the decretalists employed when summarizing the powers of office the bishop

3 Bk I, title 6

4 Bernard of Parma, Glossa ordinaria, X 1.6.41, v. ipsius, Hostiensis, Lectura, X. I.6.41, v. non reperiatur. In his history of natural rights, Richard Tuck attempted to demonstrate that Medieval canon law lacked a conception of active rights (Tuck, 1979:13-15). Tuck's historiography, as it pertains to the nature and function of rights in Medieval canon law, has been effectively refuted (Tierney, 1983:429-441; Reid, 1991:58-59). 
exercised in virtue of his status as bishop - they were powers the bishop could exercise suo iure, on his own authority. 5

The canonists frequently employed synonyms, such as facultas or potestas, that also carried the sense of legal capacity or power. The active right to vote, for instance, could sometimes be described as a facultas eligendi or a potestas eligendi. ${ }^{6}$ The word ius, however, was used most regularly to signify legal capacity, and stood at the centre of a constellation of other terms which gave to this usage greater depth and complexity (Reid, 1996:313).

\section{Legal claim}

\subsection{Van der Vyver on legal claim}

By legal claim, Van der Vyver (1988:211) means:

A right properly so-called, which comprises claims of a legal subject as against other persons to a legal object, is composed of two inherent relationships:

(a) The subject-object relationship; that is to say, the special relationship between the person having a right and the object of his right. This relationship finds expression in the fact that the subject may in some or other respect lay claim to the object. Within the confines of his right, the subject is entitled to apply the object to his own benefit. The subject-object relationship thus entails the entitlement of the person having the right to enjoy the object of his right and - still within the confines of his right - to command the utilisation of the object ...

(b) The subject-third parties relationship; that is, the relationship between the person having the right and all other legal subjects. The content this relationship gives expression to the legitimate expectation of the person having the right that the object of his right should be left intact and the exercise of his entitlements should be endured by others. Third parties, in a word, are required to refrain from any act that would obstruct or hamper the exercise of the entitlements included in the subject-object relationship.

5 The bishop's right to judge his subjects, to correct wrong-doing, to visit the territories of his diocese, and to dispense from the rigours of the law were all powers that could be exercised suo iure, by virtue of the episcopal office. This stands in contrast with special powers individual bishops might be granted from the pope, such as the power to act as a papal legate (Figuiera, 1986; Sayers, 1971)

6 See X.1.6.10 (describing the ius eligendi as a facultas eligendi), and Hostiensis, Lectura, $\mathrm{X} .1 .6 .25$, v. admittendos (describing the ius eligendi as a potestas eligendi) 


\subsection{The ius coniugale as a legal claim}

A clear example of the operation of these two aspects of a claim can be found in the ius coniugale, the "marital right" (also called the ius matrimoniale). The ius contugale had its origin in the Pauline notion of the conjugal debt. St. Paul wrote in his First Letter to the Corinthians:

Let the husband render to the wife what is her due and likewise the wife to her husband. A wife has no authority over her body, but her husband; the husband has no authority over his body, but his wife. You must not refuse each other except by consent, time, that you might give yourself to prayer, and return together again lest Satan tempt you because you lack self-control (1 Corinthians 7:3-7).

The term that is translated as "due" is the Greek word opheile. Opheile unambiguously meant what was owing. It was a debt (Liddell \& Scott, 1940:1277). In the Vulgate, St. Jerome translated opheile as debitum (Noonan, 1986:42). The sense of what was owing or due was preserved by this translation.

The canonists transformed this debitum from a moral obligation founded on Scriptural exhortation into a judicially enforceable right ${ }^{7}$ (Reid, 1991:80-91). The wife had a right to sexual relations with her husband, which the husband was legally obliged to respect, and the husband had a right to sexual relations with his wife, which the wife was equally obliged to respect (Reid, 1991:80-91).

One sees in the canonistic treatment of the ius coniugale both of the structural elements Van der Vyver has identified as forming a claim. First, one sees a "special relationship between the person having a right and the object of his right" and one sees that "this relationship finds expression in the fact that the subject may in some or other respect lay claim to the object". The marital relationship is, indeed, a "special relationship". Each party to the marital relationship, furthermore, can lay claim to sexual relations with the other party. This may be a dehumanizing way of describing a marriage. It may be evidence of the phenomenon the critical legal studies movement calls the "reification" of rights. Nevertheless, it is unambiguous evidence of the operation of claim-rights in thirteenth-century canon law.

Secondly, one also sees that "[t]he content of this relationship gives expression to the legitimate expectation of the person having the right that the object of his

7 References to a Ius matrimonii that carry the notion of a party's rights within marriage can be found as early as the late twelfth century decretists. The decretist Honorius, for instance, states regarding the operation of the Pauline privilege: "Exciptur tamen casus ubi contumelia Creatoris solvit ius matrimonii" (Grimm, 1989:282). Honorius's point is not that "the law of marriage" is dissolved by the contempt the unbeliever manifests, but that the rights of the parties to the marriage are thereby dissolved (cf. Elliott, 1993:132-194, reviewing canonistic and theological arguments on the development of the conjugal debt). 
Charles, J. Reid, Jr.

right should be left intact and the exercise of his entitlements should be endured by others" (Van der Vyver, 1988:211). This expectation is seen, for instance, in the decretalist analysis of the marriages of serfs, when the decretalists attempted to resolve the potential clash between the serf's (and his wife's) ius coniugale and the demands of his feudal lord. A serf owed his feudal lord servitium, but his wife also had the right to his sexual performance. When these expectations came into conflict, at least some decretalists argued that the wife had a "legitimate expectation" that her "entitlements should be endured" by the feudal lord, and therefore required the feudal lord to wait until the ius coniugale was satisfied before requiring service from his serf. ${ }^{8}$

\section{Legal entitlement}

\subsection{Van der Vyver on legal enfitlement}

By legal entitlement, Van der Vyver (1988:212-213) means:

A right, in its subject-object relationship, is made up of a number of entitlements ... The word 'entitlement' is here chosen to denote the lawfulness or legal permissibility of dealing in a particular way with a legal object - that is, by reason of the person performing the act having a legal right to that object..

The entitlements included in a right may comprise one or more of the following: the entitlement to use and enjoy, the entitlement to consume and destroy, and some would also say the entitlement to burden or to alienate the object of one's right.

\subsection{Canonistic distinctions between right and underlying entitlement}

The canonists sometimes distinguished between the claim one had and the underlying entitlements one was thereby permitted to exercise in virtue of the claim. Perhaps the clearest example of this distinction occurs in discussions of the ius ad rem and ius in re. The ius ad rem was the claim one might assert against third parties who threatened the security of one's right (Dondorp, 1991; Landau, 1971). The ius ad rem was developed in the context of episcopal elections as a device by which a bishop-elect might prevent third parties from interfering with his taking office (Benson, 1968:142). The ius in re, then, in the context of episcopal elections, would describe the bundle of "rights" or "entitlements" the bishop might possess, use, and enjoy (but not alienate) upon taking office (Benson, 1968:142).

8 At times of conflict between the claim of the lord to feudal service and the claim of the wife to the scxual companionship of her spouse, Bemard of Parma was willing to cede to the wife (Reid, 1991.89). Innocent IV rejected Bernard's position, but Hostiensis largely agreed with the author of the Glossa ordinaria (Reid, 1991:89-91) 
At least occasionally, the decretalists engaged in detailed analyses of the contents of the entitlements represented by particular iura, such as the ius episcopale. These analyses reflect an uneasiness with the use of the same term, ius, to convey both the meaning of a claim and the content of the underlying entitlements thus being claimed. Perhaps the most comprehensive example of this sort of analysis occurs in Hostiensis's treatment of the ius episcopale. Drawing upon the distinction between genus and species, Hostiensis asserted that the ius episcopale was a genus made up of two principal species, the lex diocesana and the lex iurisdictionis, and a large number of more "specialized" branches, such as "inquisition", "correction", and "reformation". 9

In analyzing the content of the ius episcopale in terms of genus and species, Hostiensis must have sensed the impropriety of defining the content of a particular right in terms of other rights. Properly speaking, following Van der Vyver, the content of a right does not consist of other rights, but of subordinate entitlements permitting the use of the object of the right in certain instances. The failure of Latin to provide a ready equivalent to the English word entitlement, however, seems to have stunted development in this direction.

\section{Conclusion}

This application of Van der Vyver's analysis of rights, it is hoped, has accomplished at least two objectives.

- First, it is clear that the concept of rights deployed by the thirteenth-century canonists fits all of Van der Vyver's categories. The word ius can, in appropriate circumstances, mean both legal capacity and legal claim. Canonistic analyses of rights, furthermore, as demonstrated by Hostiensis's treatment of the ius episcopale, sometimes distinguished between a particular right and the underlying entitlements of which it is comprised

- This study of Medieval canon law, it is hoped, also demonstrates the importance of Van der Vyver's conception of rights for modern analytical jurisprudence. Hohfeldian analysis has a flat quality to it, considering as it does only whether a particular right can best be denominated as a claim, a power, a liberty or an immunity. Van der Vyver's analysis has a richer

9 The lex diocesana and the lex iurisdictionis, together, formed the sum of entitlements and powers a thirteenth-century bishop might claim and exercise The term lex iurisdictionis is not, as one might suspect, related to the power of jurisdiction. Bernard of Parma argued that the lex iurisdictionis consisted of the power to give things away, while the lex diocesana consisted of the power to receive things. See Bernard of Parma, Glossa ordinaria, X. 1.31 18, v de lege iurisdictionis. More satisfactorily, Innocent IV treated this division as an arbitrary distinction of the law. See Innocent IV, Commentaria, X.3.35.1, v, vendicare. Hostiensis's analysis of the two branches is found at Lectura, X.3.37.2, v. oeconomum. 
quality to it, in that it considers both the relationship of the person claiming a particular right and the object of that right. Our application of Van der Vyver's categories to thirteenth-century canon law can be utilized in the analysis of modern legal systems as well. Johan Van der Vyver has produced an analysis of rights that is a worthy successor to Hohfeld.

\section{Bibliography}

BENSON, Robert L. 1968. The Bishop-Elect: A Study in Medieval Ecclesiastical Office Princeton, NJ Princeton University Press.

(BERNARD OF PARMA). Decretales D. Gregorii Papae IX: suae integritati una cum glossis restitutae Rome, 1582

DABIN, Jean. 1952. Le Droit subjectif. Paris : Dalloz

DONDORP, Harry. 1991. Ius ad rem als Recht, Einsetzung in en Amt zu Verlangen Tijdschrifi voor Rechstgeschiedenis, 59:85-318

ELLIOTT, Dyan. 1993. Spiritual Marriage: Sexual Abstinence in Medieval Wedlock Princeton, NJ : Princeton University Press.

FIGUEIRA, Robert C. 1986. Legatus Apostolicae Sedis: The Pope's Alter Ego According to Thirteenth-Century Canon Law. Studi Medievali, (3d series):527-574

GREGORY IX. Liber Extra. (In Friedberg, Emil, ed. 1955. Corpus Iuris Canonici, vol 2. Graz : Akademische Druck- und Verlagsanstalt )

GRIMM, Benno, ed. 1989. Die Ehelehre de Magister Honorius. Ein Beitrag zur Ehelehre der anglo-normanischen Schule. Studia Gratiana, 24

HOHFELD, Wesley Newcomb. 1923. Fundamental Legal Conceptions as Applied in Judicial Reasoning and Other Essays. New Haven, CT : Yale University Press.

HOSTIENSIS. Lectura super Decretalibus, Venice, 1581

HULL, N.E.H. 1995. Vital Schools of Jurisprudence: Roscoe Pound, Wesley Newcomb Hohfeld, and the Promotion of an Academic Jurisprudential Agenda, 1910-1919. Journal of Legal Education, 45:235-281.

INNOCENT IV Commentaria ad V Libros Decretalium, Venice, 1570.

LANDAU, Peter. 1971 Zum Ursprung des 'Ius ad rem' in der Kanonistik. (In Kuttner, Stephan, ed. Proceedings of the Third International Congress of Medieval Canon Law. Vatican City : Biblioteca apostolica Vaticana. p. 81-102.)

LEWIS, Carole. 1985. The Modern Concept of Ownership of Land. Acta Juridic. 241-266

LIDDELL, Henry George \& SCOTT, Robert. 1940. A Greek-English Lexicon Oxford Clarendon Press

MARSHALL, Paul. 1985. Dooyeweerd's Empirical Theory of Rights. (In McIntire, C T., ed. The Legacy of Herman Dooyeweerd: Reflections on Critical Philosophy in the Christian Tradition. Lanham, MD : University Press of America. p. 119-142.)

MILHOLLIN, Gary L. 1970. The Natural Moral Law of Jean Dabin American Journal of Jurisprudence, 15:116-126.

NOONAN, John T., Jr. 1986. Contraception: A History of Its Treatment by the Catholic Theologians and Canonists. Enlarged ed. Cambridge, MA : Harvard University Press

REID, Charles J., Jr. 1991. The Canonistic Contribution to the Western Rights Tradition: An Historical Inquiry. Boston College Law Review, 33:37-92.

REID, Charles J., Jr. 1996. Thirteenth-Century Canon Law and Rights: The Word ius and Its Range of Subjective Meanings. Studia Canonica, 30:295-342.

SAYERS, Jane E. 1971. Papal Judges Delegate in the Province of Canterbury, 1198-1254: A Study in Ecclesiastical Jurisdiction and Administration. London : Oxford University Press. 
SINGER, William Joseph. 1982. The Legal Rights Debate from Bentham to Hohfeld. Wisconsin Law Review. 975-1059

TIERNEY, Brian. 1983. Tuck on Rights: Some Medieval Problems. History of Political Thought, 4:429-441

TIERNEY, Brian. 1989 Origins of Natural Rights Language: Texts and Contexts. History of Political Thought, 10:615-646.

TIERNEY, Brian. 1997. The Idea of Natural Rights: Studies on Natural Rights, Natural Law, and Church Law, 1150-1625. Atlanta, GA : Scholars Press.

TUCK, Richard. 1979. Natural Rights Theories: Their Origin and Development Cambridge, UK : Cambridge University Press.

VAN DER VYVER, Johan D. 1988. The Doctrine of Private-Law Rights. (In Strauss, S.A. ed. Huldigingsbundel vir W.A Joubert. Durban : Buttersworth. p 201-246)

WITTE, John, Jr. 1993. The Development of Herman Dooyeweerd's Concept of Rights South African Law Journal, 113:543-562. 